Media Industries 4.2 (2017)

DOI: $10.3998 / \mathrm{mij} .15031809 .0004 .201$

\title{
Film Distribution in New Zealand: Industrial Organization, Power Relations, and Market Failure
}

\author{
Argelia Muñoz Larroa and Natàlia Ferrer-Roca ${ }^{1}$ \\ VICTORIA UNIVERSITY OF WELLINGTON \\ argemeister [AT] gmail.com and natalia.ferrer [AT] udg.edu
}

\begin{abstract}
:
This paper provides an overview of the distribution offeature films in New Zealand to add to the scarce literature on this topic. It studies the relationships among distributors and local producers. Based on a perspective of the political economy of culture and a review of international literature on cinema distribution, our empirical research consisted of (1) a qualitative study of interviews with feature film practitioners and (2) an industrial analysis based on media reports, documents, and statistics. As a result, we observed that the feature film distribution sector is in good shape while there is a reported market failure in the distribution of New Zealand films. Many local producers struggle to find distribution deals while those who do find them discover they are disadvantageous to producers. This paper explores some of the distribution dynamics underlying the market failure in New Zealand and suggests some possible solutions.
\end{abstract}

Keywords: Film, Distribution, Political Economy, Market Failure, New Zealand

\section{Introduction}

There has been very little research on feature-film distribution in New Zealand. A couple of exceptions include a study of the history of distribution by Geoffrey Churchman ${ }^{2}$ and Geoff Lealand's general survey on the distribution and film-going trends in the country. ${ }^{3}$ However, there is a dearth of up-to-date academic research on the economic dynamics of the distribution of feature films in New Zealand, particularly on the relationship between distribution companies and local film producers. This paper aims to shed light on those areas by 
delving into (1) a qualitative study that included semistructured interviews with feature-film practitioners and (2) an industrial analysis based on media reports, documents, and statistics. We discovered a contradiction in which the feature-film distribution sector is in good shape as it is profitable and growing, while there is a reported market failure in the distribution of New Zealand feature films. This paper teases out this apparent contradiction by breaking down some of the distribution dynamics in the country. In doing so, the New Zealand example documented here also adds empirical evidence to the dynamics of transnational distribution shaping local film industries worldwide.

Feature-film distribution in New Zealand is an intermediary phase along the film industry value chain connecting feature-film producers with final audiovisual consumers. Film distributors not only help feature films to reach audiences, but also convince these audiences to pay to experience the films. ${ }^{4}$ Furthermore, distribution deals (in the form of advance deals) are currently as important for disseminating and promoting films as they are for financing films in the first place. However, interviewees pointed out that many New Zealand featurefilm producers who need distributors to disseminate, promote, or finance films struggle to find distribution deals (find no deals), while other producers who are able to engage in distribution deals find them to be disadvantageous (lower-hand deals or no-deal options). The paper takes a closer look into why there is a market failure in the production-distribution interface in the country.

The paper is organized as follows. The "Approach and Literature Review" section presents a literature review and overview of the approach whose concepts and explanations relate to our object of study and inform our theoretical framework. The "Methodology" section explains our methodological approach while the "Film Distribution in New Zealand: Scope and Ownership" section outlines the industrial organization of feature-film distribution in New Zealand. The "Gatekeepers' Imperatives and Business Conventions: Local Producers Finding No Deals" and "The Waterfall Revenue Stream: A Lower-Hand Deal or No-Deal Option for Local Producers" sections explore distributors' imperatives vis-à-vis local producers' capabilities, as well as distribution deals and revenue streams in New Zealand. A final section discusses the outcomes of such structural arrangements.

\section{Approach and Literature Review}

Several disciplines and perspectives have contributed to the research of film distributionfrom film and communication studies, to anthropology, sociology, media economics, and business. ${ }^{5}$ In the context of such interdisciplinary body of literature, the political economy of communication (PEC) is a particular relevant approach to research our object of study: film distribution and its relations to film production.

PEC is a transdisciplinary approach that was developed mainly by media and communication scholars worldwide. Since the late 1970s, it has developed theoretical explanations on how film distribution works as a structural part of the film industry. One of the main objectives of the approach is summarized by Vincent Mosco as to study the "social relations, particularly the power relations, that mutually constitute the production, distribution and consumption of [communication] resources. ${ }^{16}$ In other words, PEC has studied film distribution in relation 
to the industry's value chain phases. The economic concept of the value chain refers to three general phases in each of which value is added to the film product':

1. Production, which focuses on the creation of film content and requires a large number of film workers involved in collective tasks, as well as large amounts of financial investment. ${ }^{8}$ High fixed and variable costs are required to produce the first copy. ${ }^{9}$

2. Distribution as an intermediary activity that acquires, manages, and administers licenses to promote, lease, wholesale, or disseminate films. At this stage, the master of a film is reproduced to be channeled into networks of organizations that allocate them to final outlets.

3. Consumption, which entails services that market or disseminate films to be consumed in several windows, such as cinema theater exhibition, physical retail and online subscriptions, television broadcasting, among others.

PEC authors studying film industries in capitalist societies around the world noted high concentration on the market shares, that is, oligopolies, ${ }^{10}$ in the phase of distribution. ${ }^{11}$ As Nicholas Garnham ${ }^{12}$ observed, compared with the high costs of film production, low or nil marginal costs are required for reproducing and distributing films, and therefore, more money is available to promote and market films. High production costs and low distribution costs mean that increasing the number of units reproduced decreases the mean costs, favoring economies of scale and promoting market expansion. Having said that, film distribution is still costly to carry out to be able to produce economies of scale as well as promote filmswhich has favored large companies. Historically, when economies of scale have been put in motion, they create barriers to entry for new competitors and facilitate the creation of oligopolies that dominate the whole value chain and obtain the biggest share of markets. ${ }^{13}$

Many authors within and outside this approach have built a consensus around the key importance of distribution. ${ }^{14}$ The structural position of distributors facilitates the flow of films to commercial outlets as well as the cash flow back to production. ${ }^{15}$ Hence, the articulation of the value chain is essential to understanding viable and unviable film industries. Garnham argued for the need

to establish a viable linkage between production on the one hand and exchange (exhibition) on the other ... making the flow of money from the widely scattered box-offices [and other outlets] back to production as efficient and rapid as possible (thus accelerating the turnover time of capital). ${ }^{16}$

As Allen Scott observed, that circuit is the "basic condition of the sustained economic wellbeing of the [industry]."17

Distribution branches of major Hollywood studios have a worldwide network to disseminate feature films for theatrical exhibition and secondary markets. ${ }^{18}$ The majors distribute not only their own studios' films, but also pictures from "independent filmmakers, who either work directly for them or have projects picked up after progress toward completion has already been made."19 While the articulation of the value chain is met by Hollywood major studios' integration with distribution and tight relations with exhibitors worldwide, regional research has shown other film industries around the world have failed to achieve such 
articulation. As their exhibition markets are integrated to major Hollywood distributors and their films, local film producers remain undercapitalized. ${ }^{20}$ In Canada, for example, Ted Magder found that the distribution market dominated by American majors meant that the "lion's share of the distribution revenues in Canada flows south of the border, contributing to the undercapitalization of Canadian production activities." ${ }^{21}$ In the United Kingdom, Gill Branston and Roy Stafford observed a very similar environment, one where 95 percent of the cinema admissions are for US films or US coproductions, while UK films fail to find a release and are dependent on being picked up by a Hollywood major (which rarely happens). ${ }^{22}$ The UK Film Council found among the weaknesses of the UK film industry the lack of integration of UK companies across production and distribution, a distribution sector that did not prioritize local films, and the pervasive undercapitalization of production companies. ${ }^{23}$ Another example is Mexico, where studies have suggested the existence of strong competition from Hollywood and the flight of capital to major transnational companies which help to explain the existence of an undercapitalized production sector. ${ }^{24}$

Because all these studies have been conducted in big market nations, the current paper contributes by adding a new dimension-the situation in a small market nation such as New Zealand-within the existing debate on interconnecting issues of globalization, economy, and film distribution of local productions. More precisely, this paper adds empirical evidence to the dynamics of transnational distribution shaping local film industries worldwide.

Despite the multiple distribution platforms and commercialization outlets currently available-such as video on demand, DVD sales, paid television, and free-to-air televisiontheatrical exhibition is the first distribution window and the earliest with direct contact with customers. ${ }^{25}$ Therefore, a theatrical release is a crucial step: its success or failure has significant impact "on the subsequent commercial performance of any film and its spin-off productions." ${ }^{26}$ In the last decade, some authors viewed the potential of online distribution to open the market to independent film producers and expand access to a wider diversity of films. ${ }^{27}$ This, however, was soon met with skepticism. The emerging players forming a new US-based oligopoly (Hulu, Amazon, Netflix, iTunes) ${ }^{28}$ deal with content aggregators that are integrated upon the traditional commercial infrastructures, ${ }^{29}$ including the licensing system and the regulation of the chronology of the different windows. Furthermore, independent online distributors are still at a disadvantageous position considering the high costs of rights management and promotion. ${ }^{30}$ So far, there is a lack of evidence that online distribution could be more effective at returning revenues to filmmakers ${ }^{31}$ and that digital technologies have eroded Hollywood major's distribution and financial power. ${ }^{32}$ Considering this context and the fact that online distribution was established relatively late in New Zealand $^{33}$ due to regulations that disincentivized it, ${ }^{34}$ this paper focuses on the traditional distribution to cinema exhibition as most New Zealand films still choose and rely on it as their first commercialization outlet.

The articulation of the value chain is-regardless of the commercialization window-the main explanatory cue informing our theoretical framework, one that is based on the principle that vertical relations (along the phases of the value chain)-and specifically, the relationships of distributors with producers-have an influence on the capitalization of film producers. Most of the international research that has collected empirical evidence on this topic has conducted a macro-level of analysis of market concentration (via admissions, box office, 
number of films) and market shares of revenue streams. However, in analyzing film distribution and its relations to production in New Zealand, this paper also engages in a meso- and micro-level of analysis - that is, an industrial analysis and an examination of business conventions, respectively-to acknowledge the specificities and complexity of the relations. In doing so, this paper contributes to the examination of the power (financial-based) relations through a more detailed analysis of the industrial organization, financial structures, and contractual relations between distributors and producers as well as their implications to producers' capitalization.

\section{Methodology}

Our empirical research on feature-film distribution in New Zealand was part of a broader study of New Zealand's film industry that drew from a body of sixty in-depth, semistructured interviews with feature-film practitioners. The interviewees included producers, distributors, exhibitors, representatives of film-related associations, and funding agency facilitators. Interviews with major-, medium-, and small-sized distributors for this research were granted anonymity so they could express their opinions without jeopardizing their jobs and their organizations' commercial sensitivities.

Interview responses were compared with each other and contextualized with secondary data (i.e., media, government and business reports, statistics, online information, and previous studies). With the use of multiple sources, we aimed to enhance the reliability of our findings and to reveal different facets of the feature-film distribution sector.

\section{Film Distribution in New Zealand: Scope and Ownership}

Film distribution in New Zealand, according to Churchman, ${ }^{35}$ started at the end of the nineteenth century with the importation of movies from countries that had been pioneers in film technology and film production. The earliest national form of organized distribution business was created in 1910 consisting of a stock of secondhand films for rent. This was followed by the establishment of New Zealand Picture Supplies (NZPS) in 1913, a national company to distribute first-run foreign films. However, by 1920, the NZPS had stopped its operations as "the major Hollywood studios made a concerted effort to gain control of film distribution the world over [including New Zealand], setting up their own local exchanges and forcing many exhibitors to accept films on their terms." ${ }^{36}$ From then on, major Hollywood studios have maintained significant control of the profitable film distribution sector in the country.

Nowadays, the distribution sector is dominated by American-based media corporationssuch as Paramount, Universal, 20th Century Fox, Disney, Sony, and Warner Bros.-and, to a lesser extent, by "Australian interests, through Australian-owned distribution companies (such as Hopscotch and Madman)." ${ }^{37}$ After almost a century of established foreign interests, major distributors' business conventions are entrenched and have shaped consumption habits, such as familiarity with Hollywood films' narratives. ${ }^{38}$ 
Since the mid-1990s, distribution has doubled its annual revenue growing by 104 percent. $^{39}$ In 2012, New Zealand box office reached NZ\$173 million. ${ }^{40}$ The distribution sector generated NZ\$48 million of value added to New Zealand's gross domestic product (GDP), directly created 197 jobs, and provided NZ\$6 million of labor income. ${ }^{41}$ It is worth asking who has benefited the most by the growth of the sector. That same year, major distribution companies and their subsidiaries concentrated 73 percent of the box office in New Zealand. ${ }^{42}$ The remaining 27 percent of the market share corresponded to Australian and New Zealand smaller businesses. It is precisely this asymmetry that will be looked at in more detail here.

By 2012, there were around forty distribution companies operating in New Zealand. ${ }^{43}$ Twenty percent of them were major companies with worldwide operations, that is, subsidiaries (such as Transmission), joint ventures (United International Pictures), and distribution branches of the Hollywood studios mentioned above. The majority of them had their distribution headquarters based in the United States (including Sony from Japan). Another 5 percent of the distribution companies in New Zealand were big firms from Australia and Canada (Village Roadshow and Hopscotch, respectively) that operate in multiple territories distributing independent films or subdistributing Hollywood films. Medium-sized distribution firms represented 17.5 percent of the companies, mostly of Australian origin and one from New Zealand (Rialto Distribution), but operating in both Australian and New Zealand territories. Finally, 57.5 percent of the companies were small-sized companies mainly from Australia (14) and a few from New Zealand (8), operating at a local level (see Figure 1). Together small- and medium-sized companies targeted niche markets and specialized in distributing for different screen formats-such as theatres, online platforms, DVD, or television broadcasting-as well as diverse genres and types of films: art-house, classic, or ethnic films, such as Chinese films.

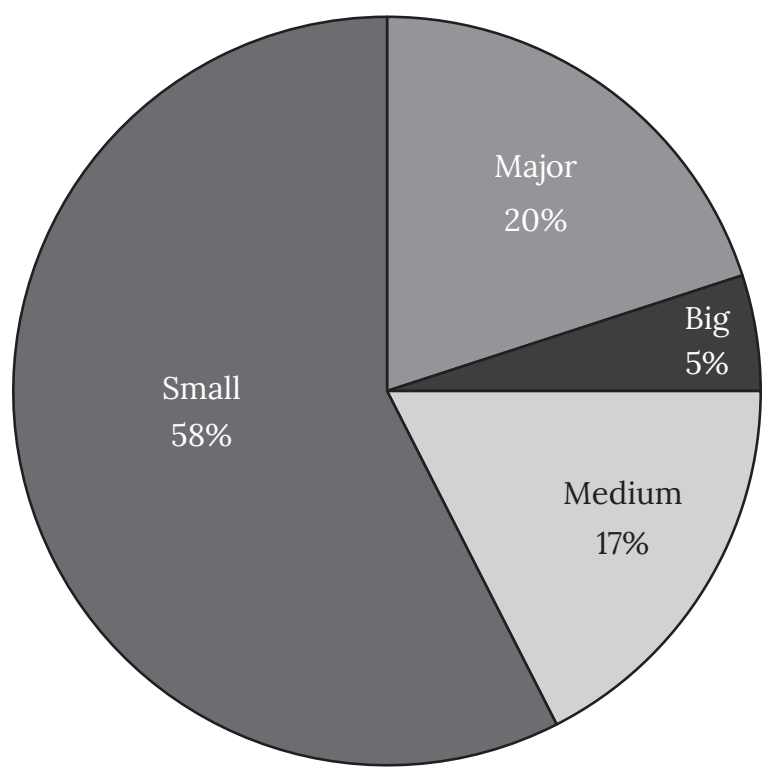

Figure 1. Size of distribution companies in New Zealand, 2012.

Source. Adapted from Muñoz Larroa, "Sustainability in the Film Industry." Based on BoxOfficeMojo.com, "2012 New Zealand and Fiji Yearly Box Office Results." 

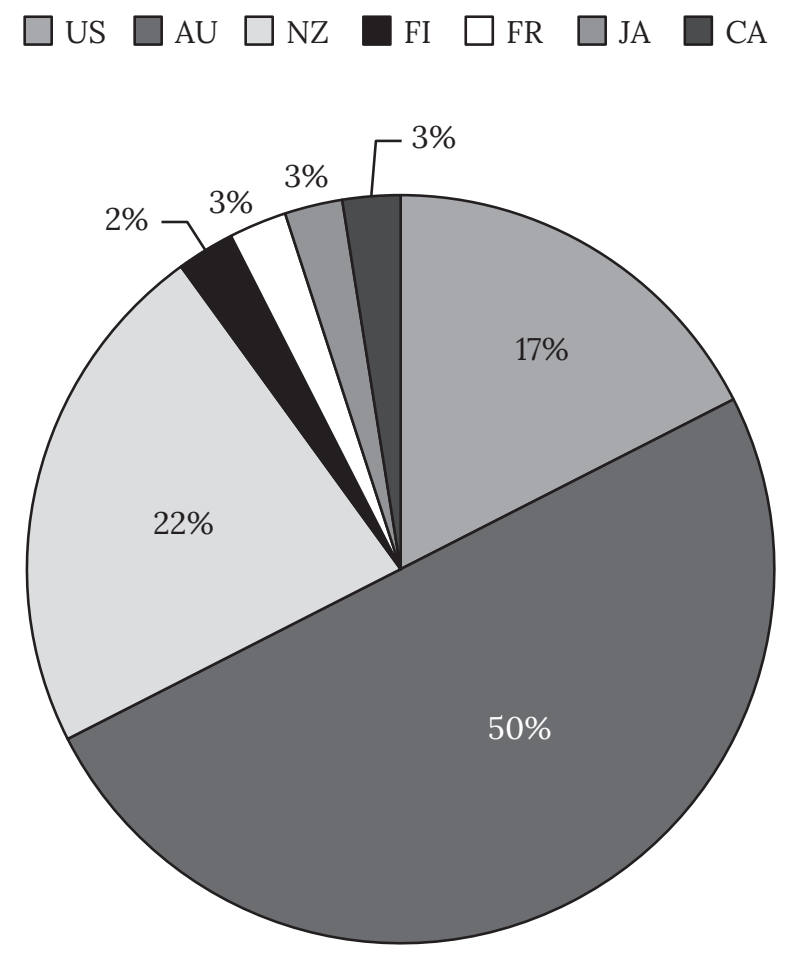

Figure 2. Ownership of distribution companies in New Zealand, 2012.

Source. Adapted from Muñoz Larroa, "Sustainability in the Film Industry." Based on BoxOfficeMojo.com, "2012 New Zealand and Fiji Yearly Box Office Results."

Note. US (United States), AU (Australia), NZ (New Zealand), FI (Fiji), FR (France), JA (Japan), CA (Canada).

Film distribution in New Zealand is a market tending to oligopoly; the most powerful distribution companies in terms of size, scope, and market share are transnational and international businesses (see Figure 2). As mentioned above, films released by majors concentrated 73 percent of the yearly box office. Also, as most distribution companies are foreign, it can be inferred that the amount of capital leaving the country through royalties and income is considerable. In 2012, 96.7 percent of the box office corresponded to films released by foreign distribution companies. By contrast, the annual revenue of films released by national distributors was NZ\$4.6 million, only 3.3 percent of the box office. ${ }^{44}$

Furthermore, the structure of distribution businesses-previously described in terms of their size, scope, and ownership-is reflected in the availability of films by origin and their market share of the box office. While US films represented 36.9 percent of the films released in New Zealand, they accounted for 53.5 percent of the box office. Other foreign countries' films-including international coproductions, US international coventures with other countries, and runaway productions, such as The Hobbit: An Unexpected Journey (dir. Peter Jackson, 2012)-represented 59.6 percent of the films released that year and accounted for 44.6 percent of the box office. New Zealand productions and coproductions totaled 3.1 percent of films released and had a market share of 1.9 percent at the box office. ${ }^{45}$

The industrial organization of the distribution sector is favored by New Zealand's economic policies. Lax fiscal regulations foster foreign investment and enhance their ability to get established in the country and repatriate profits. ${ }^{46}$ Another regulation affecting distribution was a 
temporary clause in the Copyright Bill. It was intended to help cinema exhibitors' recoupment to afford the digital switchover from 2003 to 2016, but it had secondary effects benefiting major distributors as well. Prohibiting the parallel importation of feature films to be resold within the first nine (later reduced to five) months from the first theatrical release enabled major film distributors to delay releases in New Zealand, so they could be screened during the optimal holiday periods that differed from those in the United States. The ban helped distributors of US mainstream films to maintain control over the time frame to benefit from additional windows' waterfall revenues (that is, from DVD and television among others). ${ }^{47}$

\section{Gatekeepers' Imperatives and Business Conventions: Local Producers Finding No Deals}

Distributors have a structural position that allows them to channel flows of information, resources, and products. Therefore, they are decision makers considered to be gatekeepers. The gates in view are the organizational networks that control the traffic of feature films to their final consumption outlets. ${ }^{48}$ At an organizational level, distribution begins when distribution managers become aware of the supply of films liable to receive financing through distribution advancements or to be distributed through license systems and marketing strategies. Such awareness could entail a proactive approach based on research in the market showcase, or a reactive approach such as receiving projects directly from producers or indirectly from other subsidiaries within the company or even its headquarters.

Interviews with members of small distribution companies showed that, at least in New Zealand, distributors tend to have a proactive approach and look for movie titles at international film markets and festivals to acquire licenses. This approach gives them more freedom to choose projects. However, several New Zealand film distribution managers from major and big-sized distribution companies explained that, although Australian-owned and Australian-based film distribution companies (including Hollywood majors) generally have a branch office in New Zealand, it is the Australian head office that informs the New Zealand subsidiary not only about which films to release in New Zealand, but also what the release date will be and how much financial investment is available for marketing a certain film. ${ }^{49}$ The same sources explained that New Zealand offices are consulted regarding which titles and genres of overseas films are best suited for the New Zealand cinema market in particular. However, American majors, such as 20th Century Fox, directly license the rights to distribute and market their films to New Zealand-owned companies. ${ }^{50}$ In this case, the New Zealand company receives information not only from the Australian-based office, but also directly from the American major.

Although majors' offices in New Zealand are not responsible for acquiring film rights for distribution, they are allowed to recommend New Zealand bottom- and middle-tier film projects to their company headquarters. Natàlia Ferrer-Roca describes the term bottom-tier as "feature films that have "significant New Zealand content"; depend on local capital and/or public funds to be able to cover development, production, and distribution costs; and promote New Zealand's cultural identity. ${ }^{51}$ Middle-tier films are either official coproductions or cross-border productions with a strong New Zealand component, while top-tier would comprise large-scale productions financed in Hollywood with crucial managerial and creative 
decisions tending to be made overseas. ${ }^{52}$ Under the current distribution arrangements, New Zealand feature films are not filtered by the New Zealand-based company, but film distribution proposals must go directly to the American head office for consideration.

A subsequent phase in distribution activities is to select a favorable project based on specific criteria that indicate the advantages of the film. According to major and big New Zealand distributors, when acquiring an external title (not produced in-house by the major studio), an in-depth analysis of the film's characteristics is required including actors, budget, genre, and the director's box-office record as well as a preview if possible. Distribution companies compare the production with similar feature films that have previously been released. ${ }^{53}$ Whether they are in-house or pick-up titles, in applying previous experience and professional intuition, film distribution professionals predict the New Zealand box-office revenue and, from there, work out the marketing expenses, also known as print and advertising (P\&A). ${ }^{54}$ The criteria are very similar for smaller New Zealand distributors which favor, for example, big- or medium-budget films with a well-known actor who could help promote the feature film. In sum, distributors' imperatives are securing potentially successful projects based on the distributors' "accumulation of previous practices, patterns and relationships over time."

New Zealand's bottom- and middle-tier productions go through many filters and difficulties to reach a distribution deal. The difficulties they face include a lack of social capital to open the doors and channel the script to international distribution offices, a lack of routinized administrative processes, and no star, genre, and franchise system that would confer on them a proven, positive background attractive enough to distributors.

Even for small- or medium-sized New Zealand distributors, acquiring films in overseas markets and sending back royalty reports is simpler than picking up bottom- and middle-tier local, independent films that lack routinized processes. Furthermore, independent producers expressed their concern that low budget films-especially, bottom-tier productions-are limited in terms of getting a distribution deal as "distributors will not want to even touch it." ${ }^{56}$ A large, transnational distributor confirmed this: "It is hard to get a local film to screen these days, 'cos generally it is not a big enough budget film and you are trying to get screen space competing with all Hollywood blockbuster films. ${ }^{57}$ Likewise, a small New Zealand distributor explained the reasons for disengaging from New Zealand producers such as the lack of profitability of some local, small-budget films and the fact that bigger-budget, morelikely-to-succeed local films get signed by offshore-based distribution companies (such as Transmission and Madman). All those circumstances make the common case of the majority of local producers finding no deals.

\section{The Waterfall Revenue Stream: A Lower-Hand Deal or No-Deal Option for Local Producers}

Evidence from interviews show that even local bottom- or middle-tier films that achieve international or national distribution deals with successful sales (such as Stickmen, dir. Hamish Rothwell, 2001) and box-office figures (Boy, dir. Taika Waititi, 2010) struggle to recoup production costs. ${ }^{58}$ The government-initiated report on the New Zealand Film 
Commission ${ }^{59}$ by New Zealand director Peter Jackson and Australian academic David Court confirmed that New Zealand feature-film producers hardly ever receive any profits. ${ }^{60}$ A major reason for this is that presale financial structures and revenue streamsencompassing the different intermediaries along the value chain-are disadvantageous for the independent producer. ${ }^{61}$

As mentioned in the "Approach and Literature Review" section, this happens in other countries as well. Edward Epstein observes that the power of major distributors in terms of financial capacity and extended networks around the world allows them to enforce unfavorable distribution terms. ${ }^{62}$ Although majors can provide significant advances and promotional resources, explains Gregory Goodell, the advance is paid back to the distributor out of the producers' share plus interest, which usually leaves the producer short of any return. ${ }^{63}$

In New Zealand, interviewees described how exhibitors, distributors, sales agents, and investors "take their cut and take their expenses" which accounts for "the bulk of the money," ${ }^{64}$ conditions that make up for it being a no-deal option. Ferrer-Roca's case study ${ }^{65}$ of the New Zealand production feature film Boy exemplifies the cash flow of common financial structures for New Zealand films. Based on Ferrer-Roca, ${ }^{66}$ Figure 3 illustrates the average revenue stream of Boy that made NZ\$9.3 million at the New Zealand box office. ${ }^{67}$ Under New Zealand law, 15 percent of gross box-office earnings is levied as GST (goods and services tax). The remaining 85 percent of box-office earnings is distributed between the exhibitor and the distributor. The exhibitors' share, which is, on average, 55 percent in conjunction with income from the "candy bar," is used to cover operational costs (including rent of facilities, staff salaries, and advertising) and make profits. The boxoffice percentage that cinemas have to pay to distributors for booking a feature film is called "film rental," which is the distributors' share from box-office earnings. Ferrer-Roca also points out that, for New Zealand industry standards, the highest film rental for any distribution company on a first-week release is 55 percent; this will decrease 5 percent each week up to 25 percent as an incentive for exhibitors "to keep the film in the theatre for a longer period of time." ${ }^{68}$ As stated by various interviewees, the exhibitor's share, or the distribution fee for bottom- or middle-tier New Zealand productions, is generally likely to be higher due to the risk associated in releasing a feature film from New Zealand. Generally, distributors are able to get the greatest percentages when the performance expectation of the feature film is high, such as blockbusters. In other words, a distributor would be able to get 55 percent on week 1 for The Hobbit, but would get only 25 percent for an independent film release. ${ }^{69}$

According to Figure 3, the distributor's share is divided between a distribution fee which is, on average, 25 percent-this is the main revenue for distributors and might be further divided between the New Zealand branch and the Australian-based or American office-and the recoupment of expenditure for promoting and releasing a feature film. Distribution expenses are both fixed and variable costs. On the one hand, marketing is a variable expense involving P\&A. This is calculated by film distributors on a case-by-case basis mainly depending on expected box-office performance and less often on previous agreements of minimum marketing commitments or on allocated regional marketing budgets. On the other hand, fixed costs for film distributors entail the shipping of a security-protected digital hard drive to cinemas, the Key Delivery Message encryption. To unlock the film on a digital 


\begin{tabular}{|c|c|c|}
\hline Gross Box Office Receipts in NZ & $100 \%$ & $\begin{array}{l}\text { NZD } \\
\mathbf{9 , 3 0 0 , 0 0 0}\end{array}$ \\
\hline $\begin{array}{l}\text { GST (tax) to the NZ Government } \\
\text { Subtotal A }\end{array}$ & $-15 \%$ & $\begin{array}{r}-1,395,000 \\
7,905,000\end{array}$ \\
\hline $\begin{array}{l}\text { Exhibitor's share } \\
\text { Average } \\
\text { Subtotal B }\end{array}$ & $55 \%$ of subtotal A & $\begin{array}{l}4,347,750 \\
\mathbf{4}, 347,750\end{array}$ \\
\hline $\begin{array}{l}\text { Distributor's share } \\
\text { Average } \\
\text { Subtotal C }\end{array}$ & $45 \%$ of subtotal A & $\begin{array}{l}3,557,250 \\
3,557,250\end{array}$ \\
\hline $\begin{array}{l}\text { Distributor's fee } \\
\text { Average } \\
\text { Subtotal D }\end{array}$ & $-25 \%$ of subtotal C & $\begin{array}{l}-889,312.5 \\
2,667,938\end{array}$ \\
\hline $\begin{array}{l}\text { Distributor's Recoupment of P\&A } \\
\text { Subtotal E }\end{array}$ & $-\mathrm{X}^{*}$ of subtotal D & Remaining income \\
\hline \multicolumn{2}{|c|}{ Remaining income - Production Costs } & \\
\hline \multirow[t]{2}{*}{$\begin{array}{l}\text { NZ Film Production F } \\
\text { Screen Production Inc } \\
\text { NZ on Air } \\
\text { NZFC } \\
\text { Te Māngai Pāho } \\
\text { Maori TV } \\
\text { Private Investor } \\
\text { Total }\end{array}$} & 800,000 & $\begin{array}{r}2,500,000 \\
\\
400,000 \\
250,000 \\
150,000 \\
50,000 \\
450,000 \\
5,600,000\end{array}$ \\
\hline & & ng income $-5,600,000$ \\
\hline Total & Negative balanc & vestors and Producer \\
\hline
\end{tabular}

Figure 3. Revenue stream estimates for the feature film Boy.

Source. Adapted from Ferrer-Roca, "Multi-platform Funding."

Note. This chart presents only estimates based on average percentages of business conventions. GST = goods and services tax; P\&A = print and advertising; NZFC = New Zealand Film Commission.

${ }^{\text {a}} \mathrm{P} \& A$ expenses for Boy are unknown. More precise data is not available due to companies' commercial confidentiality.

cinema's server system, the New Zealand branch office needs to send a confirmation email to the Australian or American head office validating the screening. This electronic key that includes a code which unlocks an encrypted film is controlled and generated by a film distributor and activates the content for a certain amount of time on a specific digital cinema server.$^{70}$ Although film distributors are not yet able to control the exact slots that a film is given by the cinema theatres, they are controlling the time frame in which a certain production is available to be screened. ${ }^{71}$ 
As Figure 3 illustrates, a feature film that makes NZ\$9.3 million at the New Zealand box office (such as Boy), which is considered highly successful, is able to recoup approximately NZ\$2.6 million to pay for P\&A. The remaining revenue, if any, is shared with investors and producers. Considering that Boy cost NZ\$5.6 million to make ${ }^{72}$ and that usually investors recoup ahead of the producer-even with public funding-the producer receives no return.

In sum, Figure 3 illustrates how even if the movie might have made a surplus after the distributor recouped the P\&A costs, the amount would not have been enough for investors to recover, let alone provide any return to the producer.

\section{Discussion: Market Failure}

In our analysis of the distribution sector, big disparities can be observed between a few large, internationally owned distributors that dominate the New Zealand market and local, small distributors. The market saturation by large companies increases the difficulty for smaller, local distributors to be competitive in the market. These asymmetries seem to contribute to a budget-scale mismatch. First, large distributors are not interested in local small-budget films (bottom- and middle-tier films) and tend to bring in larger-budget (top-tier) international films. Second, small local distributors who are striving to survive in an uncompetitive, oligopolistic market depend on medium- or large-budget foreign films as they are highly publicized. Consequently, potential symbiotic relations between the small distributors and local film producers are inhibited.

From a neoclassical market perspective, distributors' selection of film projects cannot be mandated and their transnationally driven, commercial imperatives do not necessarily correspond to the characteristics of local films. ${ }^{73}$ This situation has led a couple of interviewees from film-related government agencies to suggest the existence of market failure where many local films (bottom- and middle-tier productions) cannot find distribution deals. Furthermore, local films that do find distribution deals fail completely to compensate the producers' investment whereas the financial structures commonly used are designed to compensate for the risks that distributors, exhibitors, and investors incur, given the uncertainty of the movie performing well. This is another example of market failure where the reallocation of returns to each contributor of the value chain is not efficient.

The study revealed that for many independent producers in New Zealand, cinema exhibition is accepted as a nonprofitable window. In turn, many independent producers have decided to self-distribute their films working directly with cinemas. There is a common perception that if they go with a distributor, "they end up doing nothing." "W4 With self-distribution, cinemas generally get 70 percent of the box office, and each week, the figure decreases by 5 percent. Nonetheless, producers have to pay for advertising costs leading one producer to comment, "you are lucky if you break even."75 Interviewees explained that the main reason independent producers keep thinking in terms of cinema releases is so the film "travels around the country and people get to see it." ${ }^{76}$ Instead, producers expect to make money directly from international sales to territories: "[I]t is just one figure that comes back to the investors, whereas the box office is everyone taking their slice."77 The more territories a film 
is sold to, the greater the chances for returns to cover production costs or make profits. However, international sales are not easy to achieve: they require international marketing experience and skills, social capital to connect to networks, and resources to travel.

New Zealand's small population size is, of course, a factor to consider when analyzing industrial struggles as the market size is small compared with other countries. ${ }^{78}$ Some public servants stated they believed that the market size in the country is insufficient for the private sector to provide local production, hence the importation of more costeffective content. Nonetheless, John Barnett and Peter Jackson are two examples of top New Zealand producers who believe that "it is possible for local productions to turn a profit." ${ }^{79}$ More research has to be done in this area as other film industries around the world, as discussed in the "Approach and Literature Review" section, also face the issue of an undercapitalized local production sector. This indicates the problem is not unique to small-population countries, but is related to the flow of capital generated by the structural arrangements of transnational distribution.

For instance, other worldwide cash-flow models offer more efficient ways to compensate film producers. However, they are very rarely used because of a power imbalance in negotiations with distributors. One example of a different model is when filmmakers receive a share of the revenue from day 1. In New Zealand, Jackson and Court's report suggested the creation of a Box Office Incentive Scheme rewarding local box-office films with "\$1 per each $\$ 10$ of the gross box office." ${ }^{\prime 80}$ But no policy developments have been pursued in this area. ${ }^{81}$

Furthermore, as this paper shows, New Zealand films (and New Zealand coproductions) enjoy only 1.9 percent of domestic market share which makes the already-small market much smaller, especially when compared with the 30 percent of domestic market share in Denmark, another small-population country. ${ }^{82}$ This indicates the market for distribution of local films could be expanded if initiatives such as audience-development strategies are implemented. It is also important to point out the potential of New Zealand products beyond the country's borders.

The analysis made so far confirms that the small market issue is exacerbated by business conventions and the regulation of the film distribution sector in New Zealand, such as the conventional revenue streams and an environment that favors market saturation by transnational companies.

\section{Conclusion}

This paper has addressed the gap in the literature on film distribution in New Zealand. And at the same time, it has contributed to the international literature studying the influence of transnational distribution on regional film industries. In offering a more detailed analysis of the industrial organization of distribution as well as the financial structures and contractual relations with film producers in New Zealand, this paper has provided specific insights into the power (financial-based) relations between distributors and producers that help to explain producers' undercapitalization. 
Film distribution in New Zealand is mainly owned by a handful of large foreign companies. This implies the existence of barriers to entry or growth for smaller, local distributors which limits their capacity to take risks and makes them dependent on the subdistribution of Hollywood films or other international independent films with a higher promotional apparatus. The sector disparities signal market failures that are important to address. For New Zealand films, the transnationalization of film distribution means an overreliance on large corporations which have little interest on them (offering no deals) or whose power allows them to dictate the terms of the revenue streams. In this form, even for commercially successful New Zealand films, producers get the lowest margins and are at the lower end of the recoupment process (lower-hand deals). We have argued that business models for revenue streams reflect in this manner a power imbalance between independent producers on the one hand, and distributors on the other.

Although there is a current market failure in the distribution of local films, there is also potential for policy intervention (that has so far focused mainly on supporting film production). We suggest minimum standards regulating contractual relations between dissemination channels and producers to guarantee the latter a better cut and a better recoupment position. There is, for instance, the possibility of implementing schemes such as the one suggested by Jackson and Court. ${ }^{83}$ Further research is needed on how to foster audiencedevelopment strategies and alternative channels of distribution for nonmainstream exhibition and platforms of film commercialization, perhaps through public-private partnerships, to grow local distribution businesses that can afford a risk-taking attitude toward New Zealand films.

${ }^{1}$ Argelia Muñoz Larroa is a researcher with a focus on regional economic development enhanced by the sustainability of cultural industries. Having examined the film industries in Mexico, the United States, Canada, and New Zealand, she has developed a theoretical framework to guide effective policy making to support their sustainability. She has a PhD in management from Victoria University of Wellington, New Zealand; an MA in international affairs (Distinction); and a BA in history (Distinction) from Universidad Nacional Autónoma de México. Her MA dissertation received the Best Thesis Award from the Center for Research on North America, and her doctoral dissertation was honoured with the Victoria Business School Dean's Award. She has published in the International Journal of Communication, Norteamérica, and Estudios sobre las Culturas Contemporáneas. Natàlia FerrerRoca is an adjunct professor at the Department of Communication and Business Management at University of Girona, Catalonia. She has a strong international background with a $\mathrm{PhD}$ in media studies from Victoria University of Wellington (New Zealand), MA in communications policy (Distinction) from Westminster University (London), and a degree in journalism and business from the Autonomous University of Barcelona. Her research focuses on the intersection between media and communication studies, business, and place branding, with special focus on political economy. She is also Associate Editor of The Place Brand Observer (http:// placebrandobserver.com). She has published in the Journal of Media Business Studies, Place Branding and Public Diplomacy, and Studies in Australasian Cinema. 
${ }^{2}$ Geoffrey Churchman, Celluloid Dreams: A Century of Film in New Zealand (Wellington: IPL Books, 1997).

${ }^{3}$ Geoff Lealand, "A Nation of Film-Goers: Audiences, Exhibition and Distribution in New Zealand," in Watching Films: New Perspectives on Movie-Going, Exhibition and Reception, ed. Karina Aveyard and Albert Moran (Bristol, UK: Intellect, 2013).

${ }^{4}$ Jason E. Squire, The Movie Business Book (NY: Fireside, 2004).

${ }^{5}$ For anthropology, see the pioneering work of Hortense Powdermaker, Hollywood: The Dream Factory (NY: Little, Brown, 1950). For film and communication studies, see, for example, Tino Balio, The American Film Industry (Madison: University of Wisconsin Press, 1976) and Janet Wasko, Movies and Money: Financing the American Film Industry (Norwood, NJ: Ablex, 1982). For media economics, see Robert Picard, The Economics and Financing of Media Companies (NY: Fordham University Press, 2002). For a sociological and organizational perspective, see Paul Hirsch, "Cultural Industries Revisited," Organization Science 11 (2000): 356-61 and Nobuko Kawashima, "Distribution of the Arts: British Arts Centers as 'Gatekeepers' in Intersecting Cultural Production Systems," Poetics 26 (1999): 263-83. Finally, for a business perspective, see Gregory Goodell, Independent Feature Film Production: A Complete Guide from Concept through Distribution (NY: St. Martin's Griffin, 1998) and Jeffrey C. Ulin, The Business of Media Distribution: Monetizing Film, TV and Video Content in an Online World (Oxford, UK: Focal Press, 2014).

${ }^{6}$ Vincent Mosco, The Political Economy of Communication (London, UK: SAGE, 2009), 2.

${ }^{7}$ Picard, The Economics and Financing of Media Companies.

${ }^{8}$ Allen J. Scott, "A New Map of Hollywood: The Production and Distribution of American Motion Pictures," Regional Studies 36 (2002): 957-75.

${ }^{9}$ Nicholas Garnham, "From Cultural to Creative Industries," International Journal of Cultural Policy 11 (2005): 15-29.

${ }^{10}$ Defined as "control of a commodity or service in a given market by a small number of companies"; Victoria Neufeldt and David Guralnik, Webster's New World College Dictionary (NY: Macmillan, 1996), 944.

${ }^{11}$ Nicholas Garnham, Capitalism and Communication (London, UK: SAGE, 1990); Janet Wasko, How Hollywood Works (London, UK: SAGE, 2003); Asu Aksoy and Kevin Robins, "Hollywood for the 21st Century: Global Competition for Critical Mass in Image Markets," Cambridge Journal of Economics 16 (1992): 1-22; Manjunath Pendakur, Canadian Dreams and American Control: The Political Economy of the Canadian Film Industry (Detroit, MI: Wayne State University Press, 1990).

${ }^{12}$ Garnham, "From Cultural to Creative Industries"; Picard, The Economics and Financing of Media Companies; Scott, "A New Map of Hollywood."

${ }^{13}$ Aksoy and Robins, "Hollywood for the 21st Century."

${ }^{14}$ Ibid. See also Tino Balio, Hollywood in the New Millennium (Basingstoke, UK: Palgrave Macmillan, 2013), and Scott, "A New Map of Hollywood."

15 Scott, "A New Map of Hollywood."

${ }^{16}$ Garnham, Capitalism and Communication, 185.

${ }^{17}$ Scott, "A New Map of Hollywood," 969.

${ }^{18}$ Ibid. 
${ }^{19}$ Harold L. Vogel, Entertainment Industry Economics: A Guide for Financial Analysis (Cambridge, UK: Cambridge University Press, 2007), 80.

${ }^{20}$ Independent producers in the United States also face undercapitalization or subsumption to major distributors; see Aksoy and Robins, "Hollywood for the 21st Century."

${ }^{21}$ Ted Magder, "Film and Video Production," in The Cultural Industries in Canada: Problems, Policies and Prospects, ed. Michael Dorland (Toronto: James Lorimer, 1996), 152-53.

${ }^{22}$ Gill Branston and Roy Stafford, The Media Student's Book (London, UK: Routledge, 2006).

${ }^{23}$ UK Film Council, Towards a Sustainable UK Film Industry (London, UK: UK Film Council, 2000).

${ }^{24}$ Argelia Muñoz Larroa and Rodrigo Gómez García, "Analysis of the Film Production District in Mexico City," International Journal of Communication, 5, (2011): 844-74.

${ }^{25}$ Squire, The Movie Business Book, xix. See also Ulin, The Business of Media Distribution.

${ }^{26}$ Allen J. Scott, "Hollywood and the World: The Geography of Motion-Picture Distribution and Marketing," Review of International Political Economy 11 (2004): 33-61. See also Balio, Hollywood in the New Millennium; Jordi McKenzie, "How Do Theatrical Box Office Revenues Affect DVD Retail Sales? Australian Empirical Evidence," Journal of Cultural Economics 34 (2010): 159-79; Ulin, The Business of Media Distribution.

${ }^{27}$ Stuart Cunningham, Jon Silver, and John McDonnell, "Rates of Change: Online Distribution as Disruptive Technology in the Film Industry," Media International Australia, 136 (2010): 119-32.

${ }^{28}$ Ulin, The Business of Media Distribution.

${ }^{29}$ See Ramon Lobato, "The Politics of Digital Distribution: Exclusionary Structures in Online Cinema," Studies in Australasian Cinema 3 (2009): 167-78. And Chris Keall, "Why So Few Kiwi Films on iTunes? SPP Boss Explains." The National Business Review, March 3, 2012, http://www.nbr.co.nz/opinion/why-so-few-kiwi-filmsitunes-spp-boss-explains.

${ }^{30}$ See Lobato, "The Politics of Digital Distribution" and Fabien Lemercier, "Chronology: A Very Complex Equation," Cineuropa, April 18, 2017, http://cineuropa.org/nw.asp $\mathrm{x} ? \mathrm{t}=$ newsdetail\&l=en\&; $\mathrm{did}=327091$

${ }^{31}$ In establishing deals with independent producers to finance original content, the benefit of Netflix's system of cash up front, however, lacks of a backend percentage pay for dollars grossed. See Pammela McClintock, "Netflix Movies: Producers Weight Hidden Downsides," The Hollywood Reporter, March 19, 2015, http://www .hollywoodreporter.com/news /netflix-movies-producers-weigh-hidden-782403; See also Lobato, "The Politics of Digital Distribution."

${ }^{32}$ Janet Wasko, "The Death of Hollywood: Exaggeration or Reality?" in The Handbook of Political Economy of Communications, ed. Janet Wasko, Graham Murdock, and Helena Sousa (Chichester, UK: Wiley-Blackwell, 2011).

${ }^{33}$ Smaller online distributors struggled to open the market since 2011; Netflix entered in 2015 and by 2016, dominated the market alongside two large telecommunication 
companies Neon (Spark) and Lightbox (Sky TV). John Drinnan, "Sky TV's Big Battle." The New Zealand Herald, January 8, 2016, http://www.nzherald.co.nz/business / news/article.cfm?c_id=3\&;objectid=11570900.

${ }^{34}$ Such as the data cap on internet providers and a ban on parallel imports. See Dominic Kebbell, Regulatory Impact Statement: Review on Temporary Ban on Parallel Importation of Films (Wellington: Ministry of Business, Innovation and Employment, 2013), https://www.mbie.govt.nz/about-us/publications/ris/review-of-ban-onparallel-importing-of-films.pdf.

${ }^{35}$ Churchman, Celluloid Dreams.

${ }^{36}$ Ibid, 16.

${ }^{37}$ Lealand, "A Nation of Film-Goers," 148.

${ }^{38}$ See Trisha Dunleavy and Hester Joyce, New Zealand Film and Television: Institution, Industry and Cultural Change (Bristol, UK: Intellect Books, 2012) and Lealand, "A Nation of Film-Goers."

${ }^{39}$ IHS Global, "Cinema Intelligence New Zealand Database 2013," 2013, https://tech nology.ihs.com/Services/424103/cinema-intelligence-service, accessed October 31, 2013.

${ }^{40}$ Motion Picture Distributors' Association of New Zealand Incorporated (MPDANZ), "A Year of Recovery for the New Zealand Movie Industry," 2012, http://www .mpda.org.nz/wp-content/uploads /downloads/2013/01/MPDA-2012-PressRelease_2013-01.pdf.

${ }^{41}$ Pricewaterhouse Coopers, "Economic Contribution of the New Zealand Film and Television Industry," 2012, http://www.screenassociation.co.nz/uploads / features/PwCReport-ECNZ_2012.pdf.

${ }^{42}$ Figures are based on the total box office for New Zealand and Fiji territories (as also will all subsequent figures derived from this source) in 2012, US\$140 million, US\$907 million, US\$853 million; the box-office revenue for the majors and their subsidiaries was US\$103 million, US\$150 million, US\$583 million. BoxOfficeMojo. com, "2012 New Zealand and Fiji Yearly Box Office Results," accessed January 2, 2014, http://www.boxofficemojo.com/intl/newzealand/yearly/?yr=2012\& $\mathrm{p}=. \mathrm{htm}$

${ }^{43}$ See Argelia Muñoz Larroa, "Sustainability in the Film Industry: External and Internal Dynamics Shaping the Wellington Film District" (PhD diss., Victoria University of Wellington, 2015).

${ }^{44}$ Ibid.

${ }^{45}$ See Ibid. Data based on BoxOfficeMojo.com, "2012 New Zealand and Fiji Yearly Box Office Results."

${ }^{46}$ Ian Huffer, "Wellywood's Cinemas': Theatrical Film Exhibition in 'Post-industrial' Wellington," Studies in Australasian Cinema 5 (2012): 251-64.

${ }^{47}$ Muñoz Larroa, "Sustainability in the Film Industry."

${ }^{48}$ Chris Gibson, "Cultures at Work: Why Culture Matters in Research on the Cultural Industries," Social \& Cultural Geography 4 (2003): 201-15.

${ }^{49}$ Natàlia Ferrer-Roca, "Small Country, Big Films: An Analysis of the New Zealand Feature Film Industry (2002-2012)" (PhD Diss., Victoria University of Wellington, 2015). 
${ }^{50}$ The Hollywood majors also license each other when they do not have any branch office in a certain market. In New Zealand, for instance, Sony looks after Walt Disney films and Paramount takes care of Universal films.

${ }^{51}$ Natàlia Ferrer-Roca, "Multi-platform Funding Strategies for Bottom-Tier Films in Small Domestic Media Markets: Boy (2010) as a New Zealand Case Study," Journal of Media Business Studies 12 (2015): 224-37226.

${ }^{52}$ Ferrer-Roca, Natàlia. "Three-Tier Structure of the New Zealand Feature Film Industry". Studies in Australasian Cinema (2017 forthcoming).

${ }^{53}$ Ferrer-Roca, "Multi-platform Funding."

${ }^{54}$ Ibid.

${ }^{55}$ Kawashima, "Distribution of the Arts," 273.

${ }^{56}$ Independent producer, personal interview with Argelia Muñoz Larroa, August 31, 2012, Wellington.

${ }^{57}$ Manager of major distribution company, personal interview with Argelia Muñoz Larroa, July 24, 2013. Auckland.

${ }^{58}$ Ferrer-Roca, "Multi-platform Funding."

${ }^{59}$ The New Zealand Film Commission offers several funding mechanisms to assist bottom-tier production in each value chain step, including distribution. Natàlia Ferrer-Roca, "New Zealand Feature Film Funding: Between National and International Priorities," in Public Funding for Film: Industries-GovernanceInternational Cases, ed. Pobert Murschetz, Ronald Teichmann, and Matthias Karmasin (Springer, forthcoming).

${ }^{60}$ Peter Jackson and David Court, Review of the New Zealand Film Commission (Wellington: Ministry for Culture and Heritage, 2010), http://www.mch.govt.nz/ projects/culture/100628NZReport.pdf.

${ }^{61}$ See also Muñoz Larroa, "Sustainability in the Film Industry."

${ }^{62}$ Edward J. Epstein, The Big Picture: The New Logic of Money and Power in Hollywood (NY: Random House Publishing Group, 2005).

${ }^{63}$ Goodell, Independent Feature Film Production.

${ }^{64}$ Independent producer, personal interview with Argelia Muñoz Larroa, March 11, 2013, Wellington.

${ }^{65}$ Ferrer-Roca, "Multi-platform Funding.", 228-30.

${ }^{66}$ Ferrer-Roca, "Multi-platform Funding."

${ }^{67}$ After this research was conducted, the director of Boy (2010) released Hunt for the Wilderpeople (2016) which became the highest grossing New Zealand film. It made NZ\$12 million in the country, AU\$11.2 million in Australia, and US\$5 million in the United States after a limited release. There is no information available on the return to the producers; however, it is a good example that a director with a successful background has been able to negotiate better international distribution deals than for his previous work. See New Zealand Film Commission (NZFC), "New Box Office Research Available," http://www.nzfilm.co.nz/ news/new-box-office-research-available; Karl Quinn, "Australian Box Office 2016," The Sydney Morning Herald, January 4, 2017, http://www.smh.com.au/ entertainment/movies / australian-box-office-2016-we-do-love-an-animalmovie-dont-we-20170103-gtl9fv.html.; IMDb, "Hunt for the Wilderpeople Box 
Office," accessed May 12, 2017, http://www.imdb.com/title/tt4698684/ business?ref_=tt_dt_bus.

${ }^{68}$ Steven Blume, "The Revenue Streams: An Overview," in The Movie Business Book, ed. Jason E. Squire (NY: Fireside, 2014), 337.

${ }^{69}$ Ferrer-Roca, "Multi-platform Funding."

70 "Digital Cinema FAQ," IndieDCP, accessed August 18, 2014, http://indiedcp.com/ digital-cinema-faq.html.

${ }^{71}$ Ferrer-Roca, "Multi-platform Funding," 229.

${ }^{72}$ Ferrer-Roca, "Multi-platform Funding."

${ }^{73}$ For more on film production in New Zealand, see Dunleavy and Joyce, New Zealand Film and Television, Ferrer-Roca, "Small Country, Big Films," Muñoz Larroa, "Sustainability in the Film Industry."

${ }^{74}$ Independent producer, personal interview with author Argelia Muñoz Larroa, March 3, 2013, Wellington.

${ }^{75}$ Ibid.

76 Ibid.

${ }^{77}$ Independent producer, personal interview with Argelia Muñoz Larroa, March 11, 2013, Wellington.

${ }^{78}$ New Zealand has a small population and, therefore, a small domestic market which limits the possibilities to benefit from economies of scale. For more on this, see Natàlia Ferrer-Roca, "Business Innovation in the Film Industry Value Chain: A New Zealand Case Study," in International Perspectives on Business Innovation and Disruption in the Creative Industries: Film, Video and Photography, ed. Robert DeFillippi and Patrik Wikström (Cheltenham, UK and Northampton, MA: Edward Elgar, 2014), 18-36.

${ }^{79}$ See Andy Kenworthy, "All the World's a Stage," Idealog, August 2013, 53, http:// idealog.co.nz/venture/2013/08/all-worlds-stage; and Jackson and Court, Review of the New Zealand Film Commission.

${ }^{80}$ Jackson and Court, Review of the New Zealand Film Commission, 69.

${ }^{81}$ For more on this, see Muñoz Larroa, "Sustainability in the Film Industry."

${ }^{82}$ Axel Scoffier, "Denmark: A Small Film Industry with Great Shape." INA Global, January 4, 2014, http://www.inaglobal.fr/en/cinema/article/denmark-smallfilm-industry-great-shape-7515.

${ }^{83}$ Jackson and Court, Review of the New Zealand Film Commission.

\section{Bibliography}

Asu Aksoy, and Kevin Robins, "Hollywood for the 21st Century: Global Competition for Critical Mass in Image Markets." Cambridge Journal of Economics 16, no. 1 (1992): 1-22.

Balio, Tino. Hollywood in the New Millennium. Basingstoke: Palgrave Macmillan, 2013.

Balio, Tino. The American Film Industry. Madison: University of Wisconsin Press, 1976.

Blume, Steven. "The Revenue Streams: An Overview." In The Movie Business Book, edited by Jason E. Squire, 332-59. New York: Fireside, 2014. 
Branston, Gill, and Roy Stafford. The Media Student's Book. London: Routledge, 2006.

Churchman, Geoffrey. Celluloid Dreams: A Century of Film in New Zealand. Wellington: IPL Books, 1997.

Cunningham, Stuart, Jon Silver, and John McDonnell. "Rates of Change: Online Distribution as Disruptive Technology in the Film Industry." Media International Australia, 136, no. 1, (2010): 119-32.

Dunleavy, Trisha, and Hester Joyce. New Zealand Film and Television: Institution, Industry and Cultural Change. Bristol: Intellect Books, 2012.

Epstein, Edward J. The Big Picture: The New Logic of Money and Power in Hollywood. New York: Random House, 2005.

Ferrer-Roca, Natàlia. "Business Innovation in the Film Industry Value Chain: A New Zealand Case Study" In International Perspectives on Business Innovation and Disruption in the Creative Industries: Film, Video and Photography, edited by Robert DeFillippi and Patrik Wikström, 18-36. Cheltenham, UK and Northampton, MA, USA: Edward Elgar, 2014.

Ferrer-Roca, Natàlia. "Multi-platform Funding Strategies for Bottom-Tier Films in Small Domestic Media Markets: Boy (2010) as a New Zealand Case Study." Journal of Media Business Studies, 12, no. 4, (2015): 224-37.

Ferrer-Roca, Natàlia. "Small Country, Big Films: An Analysis of the New Zealand Feature Film Industry (2002-2012)." PhD Diss., Victoria University of Wellington, 2015.

Ferrer-Roca, Natàlia. "Feature Film Funding between National and International Priorities. How does New Zealand Bridge the Gap?" In State Aid for Film - An International Research Handbook, edited by Paul Murschetz, Roland Teichmann and Matthias Karmasin. Springer, forthcoming.

Ferrer-Roca, Natàlia. "Three-Tier Structure of the New Zealand Feature Film Industry". Studies in Australasian Cinema (2017 forthcoming).

Garnham, Nicholas. "From Cultural to Creative Industries." International Journal of Cultural Policy 11 (2005): 15-29.

Garnham, Nicholas. Capitalism and Communication. London: SAGE, 1990.

Gibson, Chris. "Cultures at Work: Why Culture Matters in Research on the Cultural Industries." Social \& Cultural Geography 4 (2003): 201-15.

Goodell, Gregory. Independent Feature Film Production: A Complete Guide from Concept through Distribution. New York: St. Martin's, 1998.

Hirsch, Paul. "Cultural Industries Revisited." Organization Science 11 (2000): 356-61.

Huffer, Ian. "'Wellywood's Cinemas': Theatrical Film Exhibition in 'Post-industrial'Wellington." Studies in Australasian Cinema 5 (2012): 251-64.

Kawashima, Nobuko. "Distribution of the Arts: British Arts Centres as 'Gatekeepers' in Intersecting Cultural Production Systems.” Poetics 26 (1999): 263-83. 
Lealand, Geoff. "A Nation of Film-Goers: Audiences, Exhibition and Distribution in New Zealand." In Watching Films: New Perspectives on Movie-Going, Exhibition and Reception, edited by Karina Aveyard and Albert Moran, 141-55. Bristol: Intellect, 2013.

Lobato, Ramon. "The Politics of Digital Distribution: Exclusionary Structures in Online Cinema." Studies in Australasian Cinema 3 (2009): 167-78.

Magder, Ted. "Film and Video Production." In The Cultural Industries in Canada: Problems, Policies and Prospects, edited by Michael Dorland, 145-77. Canada: James Lorimer, 1996.

McKenzie, Jordi. "How Do Theatrical Box Office Revenues Affect DVD Retail Sales? Australian Empirical Evidence." Journal of Cultural Economics 34 (2010): 159-79.

Mosco, Vincent. The Political Economy of Communication. London: SAGE, 2009.

Muñoz Larroa, Argelia and Rodrigo Gómez García. "Analysis of the Film Production District in Mexico City." International Journal of Communication, 5, (2011): 844-74.

Muñoz Larroa, Argelia. "Sustainability in the Film Industry: External and Internal Dynamics Shaping the Wellington Film District." PhD diss., Victoria University of Wellington, 2015.

Neufeldt, Victoria, and David Guralnik. Webster's New World College Dictionary. New York: Macmillan, 1996.

Pendakur, Manjunath. Canadian Dreams and American Control: The Political Economy of the Canadian Film Industry. Detroit: Wayne State University Press, 1990.

Picard, Robert. The Economics and Financing of Media Companies. New York: Fordham University Press, 2002.

Powdermaker, Hortense. Hollywood: The Dream Factory. New York: Little, Brown, 1950.

Scott, Allen J. "Hollywood and the World: The Geography of Motion-Picture Distribution and Marketing." Review of International Political Economy 11 (2004): 33-61.

Scott, Allen. J. "A New Map of Hollywood: The Production and Distribution of American Motion Pictures." Regional Studies 36 (2002): 957-75.

Squire, Jason E. The Movie Business Book. New York: Fireside, 2004.

Ulin, Jeffrey C. The Business of Media Distribution: Monetizing Film, TV and Video Content in an Online World. Oxford: Focal Press, 2014.

Vogel, Harold L. Entertainment Industry Economics: A Guide for Financial Analysis. Cambridge: Cambridge University Press, 2007.

Wasko, Janet. "The Death of Hollywood: Exaggeration or Reality?" In The Handbook of Political Economy of Communications, edited by Janet Wasko, Graham Murdock, and Helena Sousa, 307-30. Chichester: Wiley-Blackwell, 2011.

Wasko, Janet. How Hollywood Works. London: SAGE, 2003.

Wasko, Janet. Movies and Money: Financing the American Film Industry. Norwood: Ablex, 1982. 